\title{
15. LIGHT HYDROCARBONS IN SEDIMENTS OF THE NANKAI ACCRETIONARY PRISM (LEG 131, SITE 808) ${ }^{1}$
}

\author{
Ulrich Berner ${ }^{2}$ and Eckhard Faber ${ }^{2}$
}

\begin{abstract}
A suite of gas samples obtained from gas pockets and sediments of the Nankai accretionary prism (Site 808 ) has been analyzed for their gas composition and carbon and hydrogen isotope ratios. Gases collected from gas pockets between 10 and 555 mbsf consist of $\mathrm{CH}_{4}$ and $\mathrm{CO}_{2}$. Stable carbon isotope ratios of these two components point to a bacterial formation of methane via $\mathrm{CO}_{2}$-reduction that is also supported by $\mathrm{D} / \mathrm{H}$ ratios of methane. Methane desorbed from sediments by a vacuum/acid treatment is of bacterial and thermal origin. Mixing between these gas types is indicated by molecular composition and carbon isotope ratios. Diagenetic processes at low temperatures can explain ethane to pentane concentrations from 0 to 850 mbsf. Between $850 \mathrm{mbsf}$ and the basaltic basement hydrocarbon occurrences are related to catagenetic processes at elevated temperatures. Thermal alteration of organic matter is reflected through different gas parameters. Propane carbon isotope values of a sample from the zone of the frontal thrust indicate that the gas likely migrated from sediments of a higher maturity into the immature sediments at 366 mbsf.
\end{abstract}

\section{INTRODUCTION}

ODP Site 808 (Fig. 1) drilled the complete sedimentary section of the Nankai accretionary prism (Japan), penetrating the frontal thrust, décollement, and basaltic basement (Taira, Hill, Firth, et al., 1991). The primary objectives of Leg 131 were to obtain information on the temperature history, the pore fluids, the mechanical state, and the physical properties of the deformed sediments.

As the formation reactions of light hydrocarbons are strongly temperature-dependent, their analysis at Site 808 can represent a sensitive indicator for the thermal hydrocarbon generation process. They also may provide information on the thermal evolution of the accretionary prism.

Molecular gas composition and isotope ratios of individual components have been determined on gases from Site 808 to determine (1) the origin and (2) migration of hydrocarbons and (3) the thermal structure of the accreted sediments.

\section{METHODS}

At Site 808 gases from 22 gas pockets in the depth range 10-555 mbsf were expanded into glass Vacutainers on board JOIDES Resolution before cutting the liners (for detail cf. Taira, Hill, Firth, et al., 1991). In addition, 44 sediment samples were frozen at liquid nitrogen temperatures directly after cutting the cores. Gases of the frozen sediments were released by a vacuum/acid treatment of Horvitz (1972) modified by Faber and Stahl (1983). The light hydrocarbons collected by this method are gases which are dissolved in the interstitial fluids and gases which are adsorbed on the sedimentary particles. The combination of these two fractions is referred to as "sediment" gases in the text. All gas samples (sediment gases and Vacutainer gases) were analyzed for their molecular composition, their carbon, and depending on the amount, for their hydrogen isotope ratios of methane.

The molecular composition of gases was determined by standard flame ionization detector (FID) and thermal conductivity detector (TCD) analyses utilizing a Siemens Sichromat 2 gas chromatograph with a capillary pre-column $(50 \mathrm{~m})$ and $\mathrm{Al}_{2} \mathrm{O}_{3}$-filled capillary main-

\footnotetext{
${ }^{1}$ Hill, I.A., Taira, A., Firth, J.V., et al., 1993. Proc. ODP, Sci. Results, 131: College Station, TX (Ocean Drilling Program).

${ }^{2}$ Federal Institute for Geosciences and Natural Resources, Stilleweg 2, D-3000 Hannover 51, Federal Republic of Germany.
}

column $(50 \mathrm{~m})$. Nitrogen was used as a carrier gas at a flow rate of $2.93 \mathrm{~mL} / \mathrm{min}$. The chromatographic separation was carried out isothermally at $90^{\circ} \mathrm{C}$. Gas concentrations of gas pockets are reported as vol\% (Table 1), whereas gas concentrations of sediment samples are given as nanograms per gram (ng/g) wet sediment (Table 2).

For the isotope analyses the individual gas components were separated chromatographically and subsequently combusted to $\mathrm{CO}_{2}$ and $\mathrm{H}_{2} \mathrm{O}$ using a preparation line described by Dumke et al. (1989). The combustion product $\mathrm{H}_{2} \mathrm{O}$ is reduced to $\mathrm{H}_{2}$ by reaction with zinc in sealed glass tubes at $450^{\circ} \mathrm{C}$ (Coleman et al., 1982; Dumke et al., 1989). For the subsequent carbon and hydrogen isotope analyses, Finnigan MAT 251 and Finnigan Delta mass spectrometers were used. Carbon isotope values are reported in reference to the PDB (PeeDee Belemnite) standard, whereas, hydrogen isotopes refer to the SMOW (Standard Mean Ocean Water) standard. The reproducibility of isotope measurements is $0.1 \%$ for carbon and $2 \%$ for $\mathrm{D} / \mathrm{H}$ ratios, respectively. The isotope data of gases from gas pockets is given in Table 1 and isotope ratios of sediment gases are compiled in Table 2.

\section{RESULTS AND DISCUSSION}

\section{Gas Pockets}

Between the sediment surface and 3 mbsf, sulfate content of pore waters decreases from seawater concentrations to $0 \mathrm{mM}$ due to bacterial sulphate reduction (Taira, Hill, Firth, et al., 1991; Gamo et al., this volume). Gas samples have been collected from gas pockets below this zone of sulfate reduction. Between 10 and 555 mbsf gases consist predominantly of $\mathrm{CH}_{4}$ and $\mathrm{CO}_{2}$ (Table 1). Methane dominates over carbon dioxide. Ethane is only present in traces at a depth of more than $170 \mathrm{mbsf}$ (Table 1). Stable carbon isotope ratios of methane and $\mathrm{CO}_{2}$ point to a bacterial formation of methane via $\mathrm{CO}_{2}$ reduction (Fig. 2) as described by Whiticar et al. (1986). Carbon isotope values of carbon dioxide of Vacutainer gases are depleted in heavy carbon isotopes by approximately $14 \%$ compared to the $\Sigma \mathrm{CO}_{2}$ of the interstitial waters (Gamo et al., this volume). This difference can be attributed to a degassing fractionation during sample retrieval, when dissolved $\mathrm{CO}_{2}$ is released from pore waters due to the decreasing pressure. The carbon isotope ratios of $\mathrm{CO}_{2}$ of the gas pockets can therefore only be used as a rough estimate in gas characterization. However, the bacterial origin of methane in the gas pockets is supported by $\mathrm{D} / \mathrm{H}$ and ${ }^{13} \mathrm{C} /{ }^{12} \mathrm{C}$ ratios of methane (Fig. 3, "gas pockets"). Carbon isotope values of methane from gas pockets seem to be depleted in heavy carbon isotopes by only $2 \%$ compared to gases 


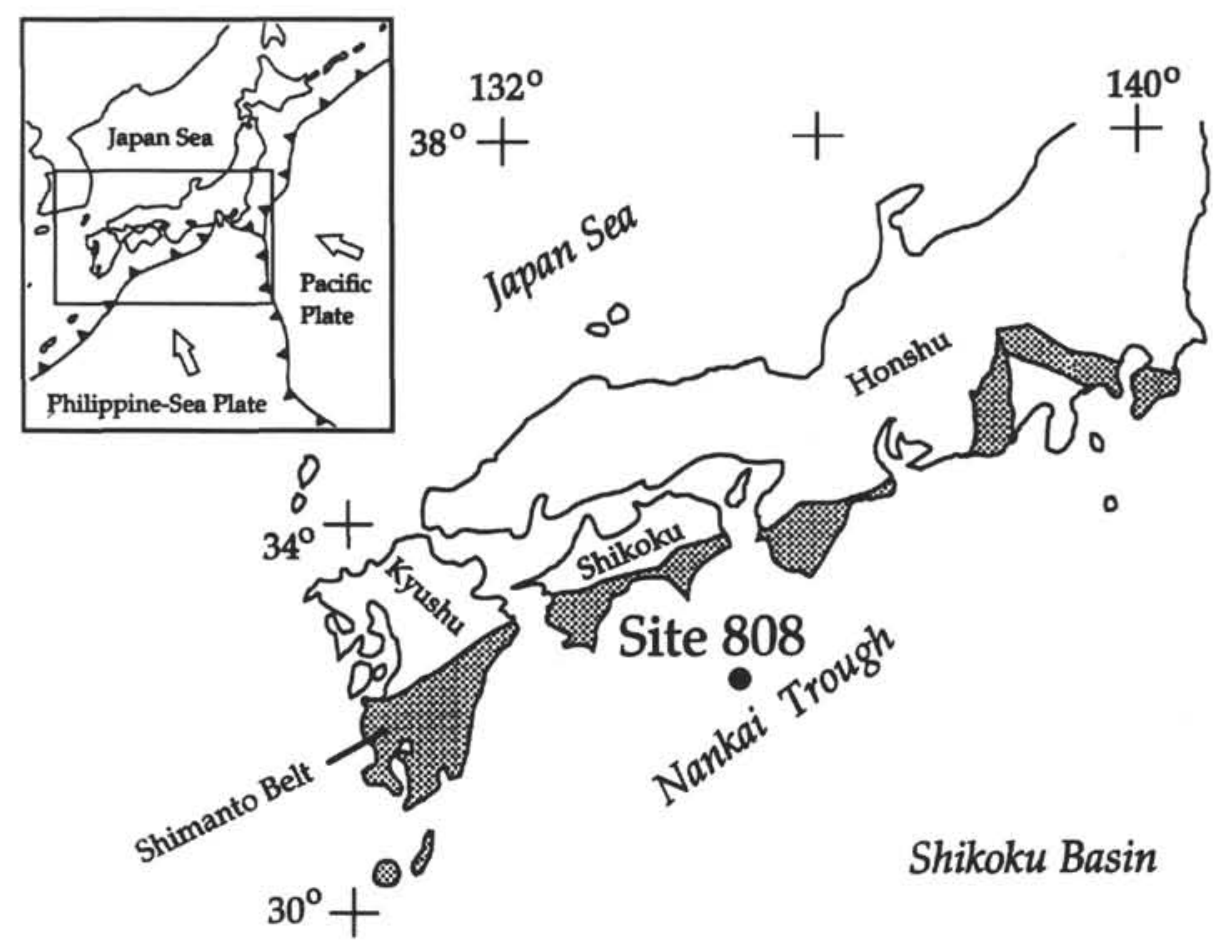

Figure 1. Location map of Site 808.

released by the vacuum/acid treatment of the sediment (Tables 1 and 2 ). The differences are also related to a slight degassing fractionation during sample retrieval, when methane is released from sediments due to decreasing pressure. The small deviation of carbon isotope ratios in methane of gas pockets still allows a realistic genetic characterization of gases.

\section{Sediment Gases}

Different from the free gases of gas pockets, which were collected from voids of the sediment, light hydrocarbons may also occur as gases dissolved in the interstitial fluids or adsorbed on sedimentary particles. A combination of these gas types is released from sediment samples by a vacuum/acid treatment and contains at Site 808 hydrocarbons methane to pentane (Table 2, Fig. 4). They are referred to as "sediment gases."

\section{Genetic Characterization of Hydrocarbons}

\section{Methane}

Methane concentration is low $(40 \mathrm{ng} / \mathrm{g}$ ) in the sediment sample from the sulfate reduction zone ( $2.95 \mathrm{mbsf})$. The concentrations increase up to two orders of magnitude below this zone (Fig. 4). Methane shows an increase of heavy carbon isotope concentrations with increasing depth between 27 and 800 mbsf (Fig. 5). Between 800 and $828 \mathrm{mbsf}$ a decrease of carbon isotope values is recognized from -58 to $-64 \%$, which is followed by an increase to $-44 \%$ at $1200 \mathrm{mbsf}$. Hydrogen isotope ratios decrease between 3 and $850 \mathrm{mbsf}$, but increase between $1000 \mathrm{mbsf}$ and the basaltic basement (Fig. 5). Based on the stable isotopic composition, methane is of bacterial origin between 3 and 1030 mbsf (Fig. 3, "sediment gases"). Bacterial reduction of $\mathrm{CO}_{2}$ (Whiticar et al., 1986) is the process by which methane is generated (Fig. 3). Two samples between $1030 \mathrm{mbsf}$ and basement are classified as thermogenic (Fig. 3). Mixing between these two gas types is suggested by a cross-correlation of molecular composition and methane carbon isotope ratios (Fig. 6).
In marine sediments also, microbial methane consumption may occur (Whiticar and Faber, 1986; Abrams, 1989; Berner et al., 1990; Berner et al., 1992). This process is preferentially observed in the sulfate reduction zone, where bacterial metabolism uses sulfate as an oxygen donator for the conversion of methane into carbon dioxide. The methane consumed in the sulfate zone has migrated from the underlying methane generation zone (cf. literature cited above). Microbial methane oxidation in the sulfate reduction zone is typically accompanied by a concentration decrease and a parallel increase of heavy carbon isotopes. The latter observation is related to a kinetic isotope effect for carbon, which has been confirmed in aerobic culture studies (Coleman et al., 1981). At Site 808, oxidation of upward-diffusing methane occurs close to the boundary between methane generation and sulfate reduction zones at $3 \mathrm{mbsf}$ as we observe a drastic decrease of methane concentrations accompanied by an increase of ${ }^{13} \mathrm{C}$ in methane (Fig. 7). Another indication for methane oxidation can be provided through the measurement of the carbon isotopic composition of the dissolved $\Sigma \mathrm{CO}_{2}$ of interstitial waters. The carbon isotope values of $\Sigma \mathrm{CO}_{2}$ typically show an increase of the light isotope near the boundary of sulfate reduction and methane reduction zones. The isotope ratios of $\Sigma \mathrm{CO}_{2}$, in some cases (Berner et al., 1992), are even less than the $\delta^{13} \mathrm{C}$ values of the particulate organic matter. Such observations were interpreted as contributions of the isotopically light carbon from oxidized bacterial methane (cf. literature cited above). Gamo et al. (this volume) report a significant ${ }^{13} \mathrm{C}$-depletion of total dissolved carbonate at $3 \mathrm{mbsf}$, close to the boundary between sulfate reduction and methane generation zones. The value of $-30 \%\left(\mathrm{\Sigma CO}_{2}\right)$ at $3 \mathrm{mbsf}$ (Fig. 7) is $6 \%$ less than the kerogen value ( $-24 \%$, Berner et al., this volume), indicating an isotopic contribution of oxidized methane.

\section{Ethane to Pentane}

Ethane is present in all sediment samples (Table 2, Fig. 4). The concentrations between 0 and $850 \mathrm{mbsf}$ are low (up to $30 \mathrm{ng} / \mathrm{g}$ ). They increase rapidly at greater depth, reaching a maximum of more than $200 \mathrm{ng} / \mathrm{g}$ sediment at about $1150 \mathrm{mbsf}$ and then drop to less than 
Table 1. Molecular composition and isotope ratios of gases from gas pockets of Site 808 .

\begin{tabular}{|c|c|c|c|c|c|c|}
\hline $\begin{array}{l}\text { Core, section, } \\
\text { interval }(\mathrm{cm})\end{array}$ & $\begin{array}{l}\text { Depth } \\
\text { (mbsf) }\end{array}$ & $\underset{\text { (vol.\%) }}{\mathrm{CO}_{2}}$ & $\underset{\text { (vol.\%) }}{\mathrm{CH}_{4}}$ & $\begin{array}{l}{ }^{13} \mathrm{C}_{\mathrm{CH} 4} \\
(\% 0)\end{array}$ & $\begin{array}{c}\delta \mathrm{D}_{\mathrm{CH} 4} \\
(\% 0)\end{array}$ & $\begin{array}{c}\delta^{13} \mathrm{C}_{\mathrm{CO} 2} \\
(\% \infty)\end{array}$ \\
\hline A- $2 \mathrm{H}-3,130-124$ & 10.60 & 0.30 & 91.30 & - & - & -1.8 \\
\hline A- $3 \mathrm{H}-3,22$ & 19.02 & 0.10 & 89.60 & -71.7 & -196 & -5.8 \\
\hline A- $-4 \mathrm{H}-4,55-60$ & 30.35 & 0.70 & 90.80 & -70.2 & -195 & -5.1 \\
\hline A-5H-6, 114-115 & 43.44 & 1.40 & 84.40 & - & - & -0.1 \\
\hline A- $6 \mathrm{H}-1,106-110$ & 45.36 & 0.80 & 89.00 & - & - & -0.7 \\
\hline A-7H- 5,22 & 60.02 & 0.10 & 61.40 & - & - & -9.4 \\
\hline $\mathrm{A}-10 \mathrm{H}-2,130-131$ & 80.60 & 0.90 & 93.90 & -68.1 & -189 & -7.1 \\
\hline $\mathrm{A}-13 \mathrm{H}-2,142-145$ & 109.32 & 1.40 & 83.40 & - & - & -0.6 \\
\hline B- 4 X- $-1,84$ & 140.74 & 0.20 & 75.80 & - & - & -11.5 \\
\hline B- $5 \mathrm{X}-1,30-32$ & 149.80 & 0.30 & 83.70 & -66.6 & -192 & -12.4 \\
\hline B- $7 \mathrm{X}-3,30$ & 172.10 & 0.30 & 83.90 & - & - & -10.6 \\
\hline B-9X-2, 91 & 190.61 & 0.40 & 62.80 & - & - & -4.7 \\
\hline B-10X-2, 74-75 & 199.64 & 0.30 & 85.60 & - & - & -7.2 \\
\hline B- $10 X-4,90-91$ & 203.10 & 0.60 & 74.30 & - & - & -6.5 \\
\hline B-11X-2, $82-83$ & 209.12 & 0.90 & 71.70 & - & - & -5.8 \\
\hline B- $13 X-2,67$ & 227.97 & 0.30 & 44.70 & -65.4 & -181 & -13.2 \\
\hline B-17X-1, 82 & 264.22 & 0.40 & 91.10 & - & - & -7.3 \\
\hline B-19X-1, 114-115 & 283.64 & 0.10 & 85.10 & - & - & -8.0 \\
\hline B- $25 X-1,64$ & 336.64 & 6.10 & 83.20 & -65.3 & -175 & -4.7 \\
\hline C- 8 R- $3,16-17$ & 369.06 & 0.10 & 71.40 & - & - & -6.7 \\
\hline C- $22 \mathrm{R}-4,0-1$ & 505.50 & 0.10 & 13.30 & -65.8 & - & - \\
\hline C- $27 R-5,0-2$ & 555.30 & 0.10 & 48.70 & -68.6 & -188 & - \\
\hline
\end{tabular}

$50 \mathrm{ng} / \mathrm{g}$ in sediments directly overlying the basaltic basement. Similar trends are observed for normal butane and normal pentane. Propane, iso-butane, and iso-pentane deviate from these vertical trends. For these components a concentration increase is observed between 360 and $680 \mathrm{mbsf}$, followed by a sharp drop in concentrations at $850 \mathrm{mbsf}$. At depths of more than $850 \mathrm{mbsf}$ propane, iso-butane and iso-pentane show the same concentration trends as ethane, $n$-butane and $n$-pentane. As sediments selected for gas analyses were fine-grained muds, and are more or less of the same lithology type, vertical concentration differences should be independent of lithology. The concentration variations of hydrocarbons ethane to pentane reflect the thermal evolution of the sedimentary organic matter at Site 808. Diagenetic processes at low temperatures could explain ethane to pentane concentrations between 0 and $850 \mathrm{mbsf}$. Between $850 \mathrm{mbsf}$ and the basaltic basement hydrocarbon occurrences are likely related to catagenetic processes at elevated temperatures (cf. Evans and Staplin, 1971; Hunt, 1979; Leythaeuser et al., 1979; Schaefer and Leythaeuser, 1983; Tissot and Welte, 1984; Rashid, 1985). This is supported by carbon isotope ratios of ethane and propane (Fig. 8, Table 3) that have values in the range of thermal hydrocarbons (Faber, 1987).

\section{Maturity and Thermal Structure}

As the formation reactions of light hydrocarbons are strongly temperature-dependent, concentration variations and isotope variations of hydrocarbon gases represent sensitive indicators for the thermal maturation process of organic matter (cf. Evans and Staplin, 1971; Durand and Espitalié, 1972; Stahl, 1977; Bernard, 1979; Alexander et al., 1983; James, 1983; Schoell, 1984; Faber, 1987; Chung et al., 1988; Jenden et al., 1988; Berner, 1989; Berner et al., 1992). Experience has shown that carbon isotope values of individual components (cf. Stahl and Carey, 1975; James, 1983; Faber, 1987; Berner, 1989) and the ratio of iso- over $n$-butane (cf. Alexander et al., 1983) may allow an estimate of the thermal evolution of the sedimentary organic matter, provided the gases were generated from an isotopically homogeneous precursor, and were not subjected to secondary alterations. In the following discussion, we try to select gas components that are likely uninfluenced by secondary alterations, and we estimate organic maturity and temperatures at Site 808 from these gas components.

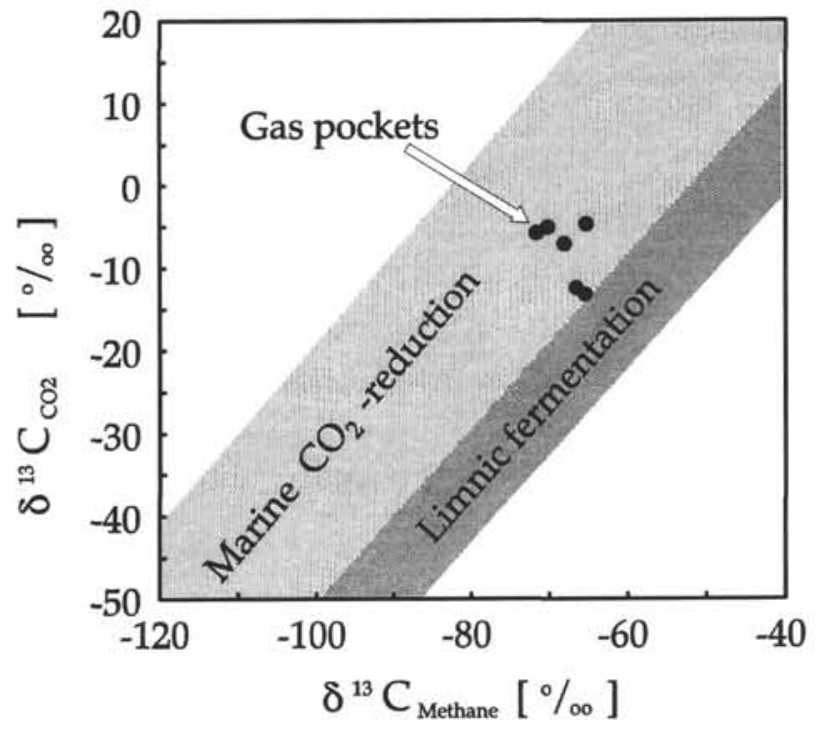

Figure 2. Carbon isotopic compositions of methane and $\mathrm{CO}_{2}$ from gas pockets at Site 808 indicate bacterial methane generation from reduction of $\mathrm{CO}_{2}$ (after Whiticar et al., 1986).

\section{Carbon Isotope Ratios}

Theoretical considerations and empirical observations (Stahl and Carey, 1975; James, 1983; Faber, 1987; Berner, 1989; Chung et al., 1988; James, 1990) suggest that individual gaseous hydrocarbons generated from cracking processes at the same temperature and maturity should show characteristic carbon isotopic compositions. Generally, methane is enriched in the light isotope compared to ethane and propane. Also, ethane normally shows lower ${ }^{13} \mathrm{C}$ concentrations than propane. These isotope trends are observed with precursors containing long-chain aliphatic molecules (Sundberg and Bennett, 1983; McCartey and Felbeck, 1986; Chung et al., 1988) which are abundant in sapropelic kerogens.

James (1990) noticed that light hydrocarbons from terrigenous organic matter can yield deviations from the normal isotope trend (s.a.). He attributed these deviations to an isotopic inhomogeneity within the precursors, which consist predominantly of aromatic structures with short aliphatic side chains.

In reservoirs and sediments, isotope trends, which have been observed for gases from sapropelic precursors, can be obscured by mixtures between different gas types of thermal and/or bacterial origin (Schoell, 1984; Faber, 1987; Berner, 1988; Chung et al., 1988; James, 1990). Experience shows that carbon isotope differences between individual gas components can be used to detect mixing between gas components of different origins.

Combining and modifying the concepts of Stahl and Carey (1975), James (1983), Schoell (1984), Faber (1987), Chung et al., 1988, and Berner (1989), carbon isotope differences of methane and ethane $\left(\delta^{13} C_{2}-\delta^{13} C_{1}: \Delta_{C 2-C 1}\right)$ and ethane and propane $\left(\delta^{13} C_{3}-\delta^{13} C_{2}: \Delta_{C 3-C 2}\right)$ are used to classify gases at Site 808 (Fig. 9). Based on data from the literature (see above), differences in isotope ratios between methane and ethane of more than $20 \%$ suggest that carbon isotope values of methane are influenced by bacterial methane production (Fig. 9). Following this classification, samples down to $1061 \mathrm{mbsf}$ are mixtures between bacterial and thermal gases.

The complexity of the gas classification at Site 808 is reflected by samples in which $\delta^{13} \mathrm{C}$ values of propane are the same or less than those of ethane. The enrichment of the heavy isotope in ethane suggests either mixing between gases of different maturity stages (Faber, 1987; Chung et al., 1988; Berner, 1989; James, 1990) or that 
Table 2. Gas concentrations in sediments of Site 808 .

\begin{tabular}{|c|c|c|c|c|c|c|c|c|}
\hline $\begin{array}{l}\text { Core, section, } \\
\text { interval }(\mathrm{cm})\end{array}$ & $\begin{array}{l}\text { Depth } \\
\text { (mbsf) }\end{array}$ & $\underset{(\mathrm{ng} / \mathrm{g})}{\mathrm{CH}_{4}}$ & $\begin{array}{l}\mathrm{C}_{2} \mathrm{H}_{6} \\
\text { (ng/g) }\end{array}$ & $\begin{array}{l}\mathrm{C}_{3} \mathrm{H}_{8} \\
\text { (ng/g) }\end{array}$ & $\underset{\text { (ng/g) }}{\mathrm{iC}_{4}}$ & $\begin{array}{c}\mathrm{nC}_{4} \\
(\mathrm{ng} / \mathrm{g})\end{array}$ & $\begin{array}{c}\mathrm{iC}_{5} \\
(\mathrm{ng} / \mathrm{g})\end{array}$ & $\begin{array}{c}\mathrm{nC}_{5} \\
(\mathrm{ng} / \mathrm{g})\end{array}$ \\
\hline \multicolumn{9}{|l|}{$113-808$ - } \\
\hline A-1H-2, 145-150 & 2.95 & 40 & 2.4 & 2.1 & 0.6 & 0.7 & 0.6 & 0.4 \\
\hline$A-4 H-2,0-5$ & 26.80 & 3492 & 2.0 & 1.9 & 0.0 & 0.0 & 0.0 & 0.0 \\
\hline A-7H-1, 145-150 & 55.25 & 206 & 2.2 & 2.3 & 0.8 & 0.9 & 1.2 & 1.2 \\
\hline A- $10 \mathrm{H}-3,15-20$ & 80.95 & 556 & 3.1 & 6.0 & 2.2 & 1.6 & 3.3 & 1.2 \\
\hline A-13H-2, $145-150$ & 108.69 & 872 & 3.8 & 0.7 & 0.6 & 0.6 & 0.8 & 1.1 \\
\hline B- $5 X-1$ & 149.50 & 922 & 3.0 & 5.4 & 3.0 & 1.7 & 2.1 & 0.8 \\
\hline B-7X-1 & 168.80 & 708 & 4.8 & 4.1 & 2.1 & 1.3 & 2.9 & 0.9 \\
\hline B-13X-1 & 225.80 & 1100 & 8.7 & 4.0 & 2.0 & 2.0 & 2.5 & 1.0 \\
\hline B-17X-2 & 264.90 & 691 & 2.3 & 4.4 & 1.0 & 1.0 & 1.3 & 0.7 \\
\hline B-20X-1 & 287.90 & 1564 & 2.3 & 0.9 & 0.6 & 0.6 & 0.7 & 0.7 \\
\hline C- 4 R-1 & 327.20 & 849 & 4.8 & 3.3 & 1.6 & 0.9 & 1.2 & 0.4 \\
\hline B- $24 X-2$ & 327.90 & 3605 & 10.9 & 8.0 & 3.9 & 2.6 & 4.9 & 1.7 \\
\hline C- $8 \mathrm{R}-1$ & 365.90 & 871 & 5.8 & 4.8 & 2.2 & 1.0 & 1.6 & 0.8 \\
\hline C-11R-2 & 396.30 & 718 & 8.9 & 9.2 & 4.8 & 2.6 & 4.6 & 1.0 \\
\hline C-14R-3 & 427.00 & 924 & 5.9 & 4.6 & 2.7 & 1.4 & 2.9 & 2.0 \\
\hline C-17R-1 & 452.70 & 1231 & 10.0 & 13.7 & 8.1 & 1.4 & 6.7 & 0.0 \\
\hline C- $-20 \mathrm{R}-1$ & 481.70 & 841 & 6.5 & 10.5 & 5.6 & 0.9 & 3.8 & 0.8 \\
\hline C-23R-1 & 510.70 & 153 & 3.1 & 5.6 & 2.4 & 0.6 & 1.1 & 0.0 \\
\hline C-26R-3 & 542.70 & 199 & 4.2 & 10.0 & 4.6 & 0.8 & 2.0 & 0.3 \\
\hline C-29R-4 & 573.10 & 2534 & 14.9 & 38.1 & 13.9 & 4.6 & 8.1 & 0.0 \\
\hline C- $32 R-3$ & 600.30 & 1200 & 5.7 & 30.8 & 7.5 & 1.3 & 5.5 & 1.1 \\
\hline C-35R-4 & 630.70 & 234 & 1.6 & 13.1 & 5.1 & 0.7 & 3.4 & 1.0 \\
\hline C-38R-4 & 659.40 & 1077 & 8.6 & 76.8 & 16.6 & 1.6 & 8.5 & 1.1 \\
\hline C-41R-1 & 683.80 & 3059 & 30.9 & 169.8 & 41.3 & 9.2 & 68.4 & 4.2 \\
\hline C- $44 \mathrm{R}-1$ & 712.40 & 735 & 5.0 & 59.1 & 13.6 & 1.9 & 6.2 & 0.7 \\
\hline C- $-47 R-3$ & 744.40 & 466 & 9.9 & 55.5 & 13.2 & 2.7 & 9.9 & 0.5 \\
\hline C-50R-5 & 776.40 & 371 & 6.0 & 51.3 & 16.0 & 2.2 & 11.4 & 0.7 \\
\hline C- 53 R-1 & 799.40 & 706 & 11.4 & 55.5 & 17.2 & 2.7 & 17.0 & 2.0 \\
\hline C-56R-1 & 828.40 & 3113 & 11.1 & 18.9 & 5.7 & 1.1 & 2.8 & 0.0 \\
\hline C-59R-2 & 858.60 & 3572 & 19.5 & 19.8 & 5.2 & 2.6 & 1.6 & 1.7 \\
\hline C- $62 \mathrm{R}-3,0-5$ & 889.10 & 2978 & 28.7 & 21.5 & 4.4 & 3.3 & 2.7 & 2.7 \\
\hline C- $65 \mathrm{R}-1,145-150$ & 916.55 & 2378 & 31.6 & 22.5 & 6.1 & 3.5 & 3.2 & 1.0 \\
\hline C- $68 \mathrm{R}-1,15-20$ & 944.35 & 1633 & 32.7 & 22.9 & 4.8 & 4.8 & 3.0 & 2.9 \\
\hline C-7IR-2, 115-120 & 975.75 & 2533 & 74.6 & 47.2 & 10.4 & 11.3 & 8.2 & 5.9 \\
\hline$C-74 R-2,0-5$ & 1003.30 & 1140 & 41.4 & 26.8 & 3.8 & 5.1 & 2.1 & 2.5 \\
\hline C-77R-1, 0-5 & 1029.90 & 851 & 33.3 & 18.8 & 2.5 & 3.5 & 1.6 & 1.5 \\
\hline C- $80 \mathrm{R}-2,120-125$ & 1060.50 & 1413 & 83.6 & 49.7 & 7.5 & 8.1 & 2.7 & 4.7 \\
\hline C- $84 \mathrm{R}-1$ & 1092.00 & 875 & 78.0 & 54.4 & 11.7 & 12.0 & 4.7 & 7.2 \\
\hline C-87R-1 & 1117.60 & 451 & 43.2 & 27.3 & 5.5 & 5.7 & 2.0 & 3.1 \\
\hline C- $90 \mathrm{R}-1$ & 1146.30 & 918 & 107.6 & 79.5 & 27.4 & 19.3 & 7.8 & 10.6 \\
\hline C-94R-1 & 1184.90 & 1831 & 239.5 & 181.0 & 74.1 & 40.4 & 12.1 & 20.5 \\
\hline C-97R-1 & 1214.00 & 279 & 28.5 & 14.0 & 1.9 & 2.9 & 0.8 & 1.7 \\
\hline C-102R-1 & 1261.50 & 1013 & 62.6 & 17.7 & 0.8 & 1.9 & 0.0 & 1.0 \\
\hline C- $-103 R-2$ & 1272.40 & 615 & 54.4 & 29.7 & 7.0 & 10.1 & 7.4 & 3.8 \\
\hline
\end{tabular}

ethane and propane have different precursor sites within the kerogen. It is likely that gases generated in the sediments between 659 and 859 mbsf, and also samples at 917 mbsf, 1030 mbsf, 1092 mbsf, 1118 mbsf, and 1214 mbsf have either experienced a contribution from gases of a higher maturity or the precursors of ethane and propane are isotopically different. Only four samples from the deepest part of Site 808 (1146, 1185, 1262 and 1272 mbsf) are likely to be uninfluenced.

As the thermal signature of methane isotope data is partly obscured by a bacterial contribution, and the carbon isotope ratios of ethane could have been influenced by mixing of ethane from a higher maturity, we compare carbon isotope ratios of propane to measured vitrinite reflectance values of Berner and Koch (this volume). Propane isotope ratios and reflectance values increase with increasing depth between $650 \mathrm{mbsf}$ and basement (Fig. 10). This suggests that propane isotope values are closely related to the maturity of the organic matter. A model that allows a comparison between isotope values of individual gas components and vitrinite reflectance data has been published by Faber (1987). The model is based on empirical observations on carbon isotope values of reservoir gases and the maturity of the related source rocks of Paleozoic age. Different from the isotope separation model of James (1983), the model of Faber (1987) is closely related to the isotopic composition of the source rock. The original model of Faber (1987) assumes an average carbon isotopic composition of Paleozoic kerogens of $-27.5 \%$. As the meas- ured isotope values of kerogens at Site 808 are around -24\%o (Berner and Koch, this volume), we have slightly modified the original concept of Faber (1987). Taking into account the observed isotope shift of $3.5 \%$, the equation

$$
\delta^{13} C_{3}=20.9 \log _{10} R_{o}-29.7
$$

of Faber (1987) has been changed into

$$
\delta^{13} C_{3}=20.9 \log _{10} R_{o}-26.2
$$

Using equation (2), calculated vitrinite reflectance values (Fig. 10) show a good coincidence with measured data of Berner and Koch (this volume). This coincidence suggests that at Site 808 the carbon isotope ratios of propane are controlled by kinetic isotope effects during cracking of kerogens.

\section{Butane Ratios}

According to Alexander et al. (1983), the butane ratio (i- $\left.\mathrm{C}_{4} / n-\mathrm{C}_{4}\right)$ indicates the boundary between diagenetic and catagenetic hydrocarbon formation. At Site 808 the butane ratio increases from 1 at $3 \mathrm{mbsf}$ to 10 at $660 \mathrm{mbsf}$ and then decreases rapidly to 2 at $860 \mathrm{mbsf}$. Between 860 and 1272 mbsf only a slight decrease from 2 to 0.6 is observed 


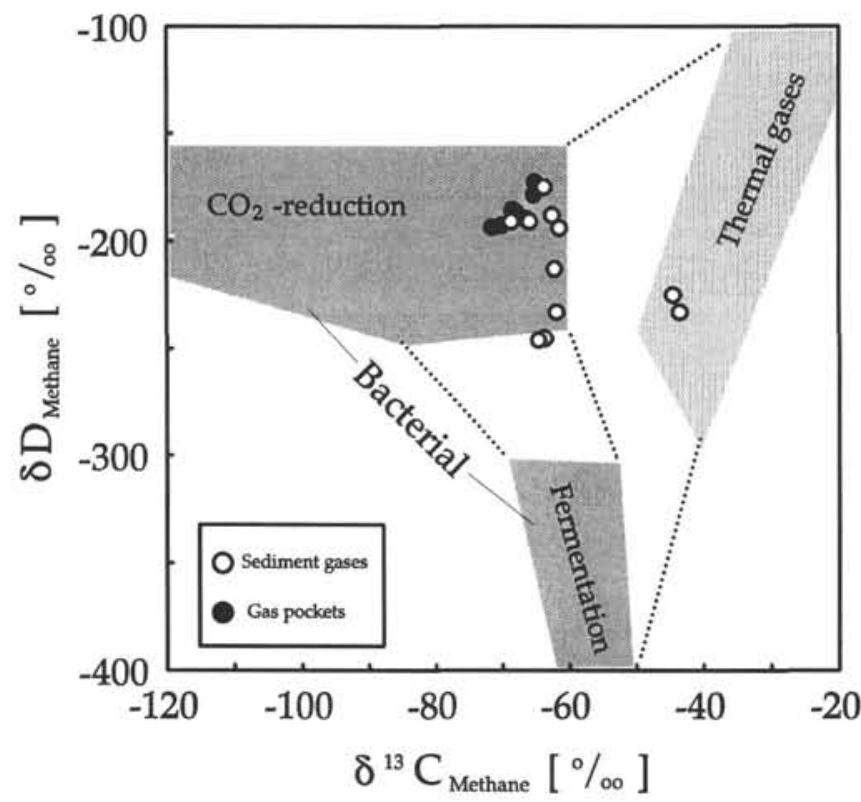

Figure 3. Carbon and hydrogen isotopic compositions of methane from gas pockets and sediment gases of Site 808 indicate bacterial methane generation from reduction of $\mathrm{CO}_{2}$ (after Whiticar et al., 1986). Two sediment gases are derived from thermal decomposition of organic matter.

(Fig. 10). Following Alexander et al. (1983), maximum values of the butane ratio, which mark the late diagenetic stage of kerogen maturity, are reached at sediment temperatures between $42^{\circ}$ and $54^{\circ} \mathrm{C}$. The decrease from elevated values of 10 to 2 marks the transition between diagenesis and catagenesis (Alexander et al., 1983) which suggests that at a depth of more than $850 \mathrm{mbsf}$, kerogens already should have reached the catagenetic stage. Butane ratios of $0.7-0.4$ below 1200 mbsf could indicate temperatures of about $100^{\circ}-120^{\circ} \mathrm{C}$ (Alexander et al., 1983). Temperature estimates derived from the model of Alexander et al. (1983) are close to the temperatures reported for Site 808 (Fig. 10) by Taira, Hill, Firth, et al. (1991). Furthermore, vitrinite reflectance measurements of Berner and Koch (this volume) show that the transition from late diagenesis to catagenesis occurs between 800 and $900 \mathrm{mbsf}$, which confirms the interpretation derived from the butane ratios (Fig. 10).

The observed similarities between geochemical models and measured temperature and maturity data (Fig. 10) suggest that at Site 808 higher homologous propane and butanes are likely related to in-situ generation. The same could apply to pentanes, as pentane ratios show a similar trend as butane ratios (Fig. 10).

\section{In-Situ Generation}

One major objective of Leg 131 was to obtain information on migration of pore fluids. Shipboard analyses of different geochemical species (Taira, Hill, Firth, et al., 1991) could not support fluid movement within the sedimentary column. Molecular composition of gaseous hydrocarbons analyzed with shipboard facilities also gave no indication of migration (Taira, Hill, Firth, et al., 1991). As isotope ratios of single gas components can be helpful in detecting allochthonous hydrocarbons (Faber, 1987; Berner and Faber, 1988; Berner and Bertrand, 1991), we will apply this tool to the gases of Site 808 .

Between 3 and 1030 mbsf, carbon and hydrogen isotope values of methane indicate a bacterial origin (Figs. 5 and 11). Whiticar et al. (1986) have demonstrated the close relationship between hydrogen isotopic composition of bacterial methane and corresponding pore waters:

$$
\delta D_{C_{4}}=\delta D_{H_{2} \mathrm{O}}-180
$$

This relation was used by Berner and Bertrand (1991) to differentiate in-situ-generated from migrated methane at Site 768 (Sulu Sea). For Site 808 , Kastner et al. (this volume) report a decrease of hydrogen isotope ratios of pore waters with increasing depth (Fig. 11A). Using the trend of Kastner et al. (this volume) and equation (3) (Whiticar et al., 1986) we estimate the hydrogen isotopic composition of methane that would result from bacterial $\mathrm{CO}_{2}$-reduction (Fig. 11A, " $\mathrm{CH}_{4}$-model"). We also take into account that the methane isotope values may deviate from the model by $\pm 10 \%$ (Whiticar et al., 1986). Between 3 and 500 mbsf, hydrogen isotope values of methane are fairly well approximated by the model, which could indicate that in this depth interval of Site 808 , methane is related to bacterial in-situ production. Below $600 \mathrm{mbsf}$, hydrogen isotope values of methane deviate significantly from the theoretical trend (Fig. 11A). This deviation suggests that a major portion of the methane between 600 and 1000 mbsf was not generated by bacterial activity only, but may be related to mixing of bacterial and thermal methanes.

\section{Re-equilibration?}

The above interpretation is supported by a comparison between carbon isotope ratios of total dissolved carbon dioxide and methane. The isotope values of dissolved $\Sigma \mathrm{CO}_{2}$ decrease constantly (Fig. 11B) with increasing depth (Gamo et al., this volume) and approach values of the organic matter (Berner and Koch, this volume). Gamo et al. (this volume) relate the vertical carbon isotope variations of dissolved $\mathrm{SCO}_{2}$ to the thermal decomposition of the sedimentary organic matter. Carbon isotope ratios of methane, however, show an opposite trend with increasing depth (Fig. 11B). If bacterial methane was generated in situ between 10 and $1000 \mathrm{mbsf}$, and carbon isotope re-equilibration (Richet et al., 1977) between $\mathrm{CH}_{4}$ and $\mathrm{CO}_{2}$ is negligible, than carbon isotope ratios of both components should follow similar trends as methane isotope values are closely related to the carbon isotope ratios of carbon dioxide (Whiticar et al., 1986). This is obviously not the case at Site 808 .

Games and Hayes (1976) noticed that fractionations between $\mathrm{CO}_{2}$ and methane in marine sediments closely approach thermodynamic equilibrium, which would result in decreasing isotope fractionation with increasing sediment temperature and could explain the variability of fractionation factors $\alpha_{\mathrm{CO}}-\mathrm{CH}_{4}$ of bacterial $\mathrm{CO}_{2}$-reduction (1.09-1.05) as reported by Whiticar et al. (1986). An approximation by Whiticar et al. (1986) of the fractionation model of Richet et al. (1977) suggests that the fractionation factor a is related to the temperature $T(K)$ by

$$
\alpha=e^{\frac{29.2}{\tau}-0.0296}
$$

The carbon isotope fractionation factors $\alpha_{\mathrm{CO}_{2}-\mathrm{CH}_{4}}$ are related to the $\delta$-values of methane and carbon dioxide by

$$
\alpha=\frac{\delta^{13} \mathrm{C}_{\mathrm{CO}_{2}}+1000}{\delta^{13} \mathrm{C}_{\mathrm{CH}_{4}}+1000}
$$

Using the temperature distribution at Site 808 (Taira, Hill, Firth, et al., 1991) and the isotope trend of Gamo et al. (this volume), we have calculated from (4) and (5) the theoretical carbon isotope variations of methane at Site 808 (Fig. 11B), assuming isotope re-equilibration between methane and carbon dioxide. The fractionation factors derived from the model vary between 1.079 at 10 mbsf to 1.053 at 1000 mbsf.

Obviously, the model does not approximate the measured carbon isotope values between 10 and 380 mbsf. The isotopic differences in this depth interval are higher than those predicted from the model, suggesting that at temperatures between $4^{\circ}$ and $40^{\circ} \mathrm{C}$, times were too short to allow re-equilibration. This in turn suggests that methane isotope values between 10 and $380 \mathrm{mbsf}$ are related to kinetic isotope 


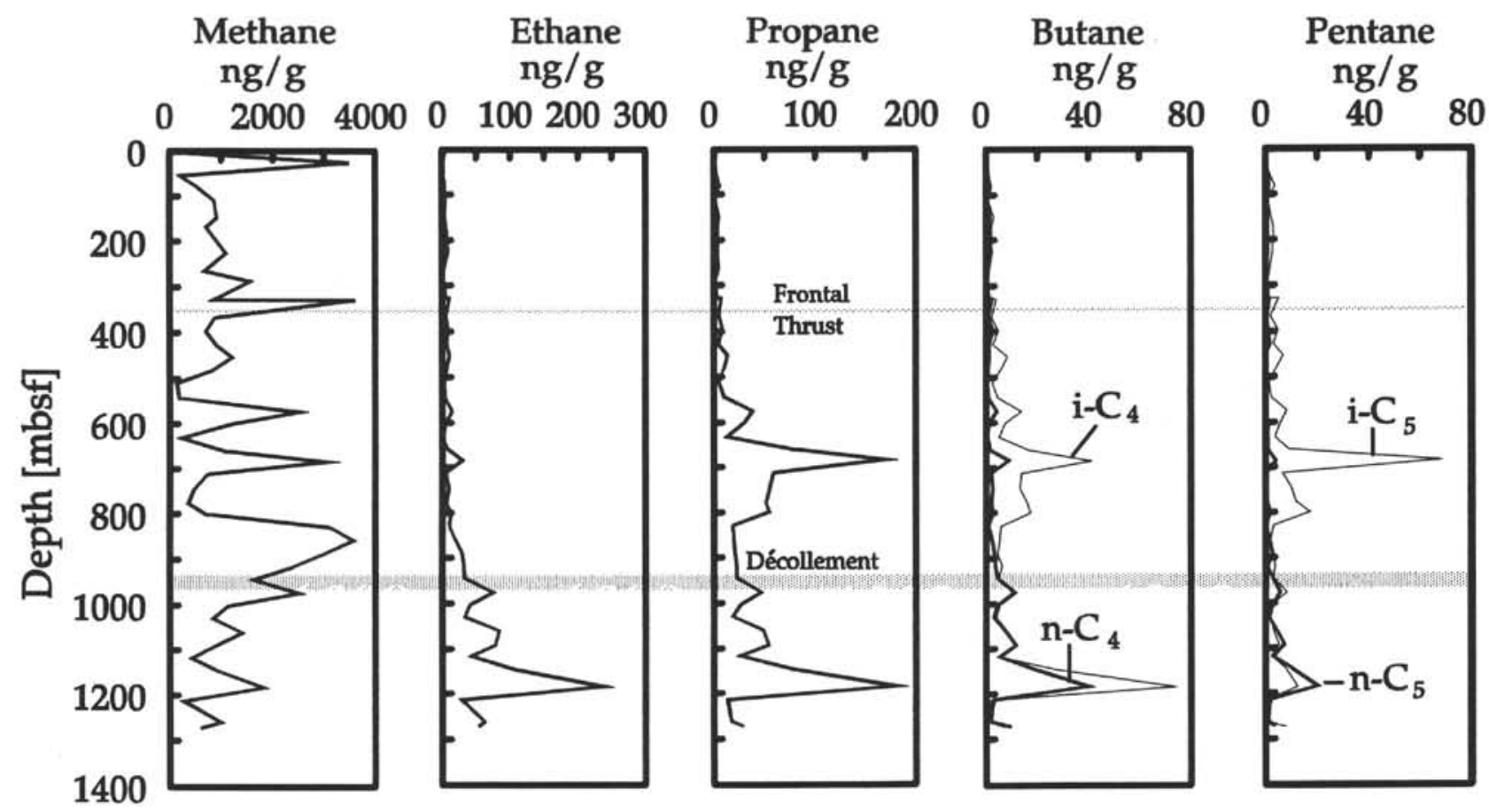

Figure 4. Gas concentrations (nanogram gas per gram wet sediment) at Site 808.

effects rather than to re-equilibration. Between 380 and $600 \mathrm{mbsf}$, measured data however are fairly well approximated by the model, suggesting that re-equilibration between methane and carbon dioxide could be responsible for the observed methane isotope ratios. Below $600 \mathrm{mbsf}$ methane isotope values are shifted to higher values with respect to the model. As the calculated fractionation factors between 600 and $1000 \mathrm{mbsf}$ are among the lowest observed for bacterial $\mathrm{CO}_{2}$-reduction ( $\alpha: 1.06$ to 1.053 ), the deviation of the measured data from the model could suggest that methane of this depth interval either represents mixtures between bacterial and thermal methanes or that bacterial methane formed at other sites of the sedimentary column migrated into the depth section between 600 and 1000 mbsf.

\section{Migration?}

In four gas samples between 683 and 917 mbsf, carbon isotope ratios of ethane are greater than those of propane (Figs. 8 and 9). The isotope differences between the two components suggest either mixing of gases from different sources (Berner, 1988; Chung et al., 1988; James, 1990) or isotopically different precursor sites of ethane and propane within the kerogens.

The mixing hypothesis implies that a portion of the ethane of these samples has migrated from sediments of a higher maturity. Propane, butanes and pentanes, however, seem to be uninfluenced by mixing, as $\delta^{13} \mathrm{C}$-values of propane, butane, and pentane ratios obviously correlate with maturity (Fig. 10). Provided that the mixing hypothesis is correct, we have to assume that ethane migrates easier than the higher homologous hydrocarbons. Such a separation may be explained by the different molecular sizes of ethane and higher hydrocarbons and suggests diffusive migration of gases. However, at a depth of more than $830 \mathrm{mbsf}$, we observe a parallel concentration increase of all components ethane to pentanes with increasing depth (Fig. 4). This increase correlates with maturity and temperature, and suggests that ethane concentrations can as well be explained through an increase of maturity. If we, however, regard the concentration decrease of ethane above the décollement as diffusion-induced, then we should expect a decrease of the $\delta$-values of ethane with decreasing concentrations (cf. Fuex, 1977, and references therein). But, obviously, carbon isotope values of ethane do not show significant changes above the décollement (Fig. 8), which in turn suggests that isotope ratios of ethane cannot be explained by diffusion. Also, vertical bulk migration of light hydrocarbons as solution in pore waters seems unlikely, as there are no indications of vertical water movement at Site 808 (cf. Gieskes et al., this volume; Kastner et al., this volume).

As gas geochemical parameters do not support vertical migration at Site 808 , we assume that ethane and propane in samples between $684 \mathrm{mbsf}$ and the décollement are generated from isotopically different precursors within the kerogen. The inversion of isotope ratios of ethane and propane is likely related to the type of kerogen. In sediments of Site 808 terrigenous organic matter is abundant (cf. Berner and Koch, this volume), which suggests that kerogens predominantly consist of aromatic structures with short aliphatic sidechains, from which hydrocarbons are generated. According to Galimov (1980), the isotopic compositions of these aliphatic sidechains can vary, and are controlled through thermodynamics. Such an isotopic inhomogeneity could in turn explain the isotopic inversion of ethane and propane if we assume that the precursors of ethane are enriched in ${ }^{13} \mathrm{C}$, compared to the precursors of propane. The same could apply to samples at 1092,1118 , and 1214 mbsf.

The isotope ratio of propane of a gas from the frontal thrust (366 mbsf) is similar to values observed at and below the décollement (Fig. 8). As the frontal thrust reaches down to the décollement (Taira, Hill, Firth, et al., 1991) it seems likely that the gases have migrated upward from this level. Using equation (3), the carbon isotope ratio of propane from the frontal thrust points to a maturity of $0.64 \%$ vitrinite reflectance equivalent, which is close to values measured at the décollement (Berner and Koch, this volume). Migration of hydrocarbons in solution is not supported by results of pore water analyses, as no geochemical signature points to water movement along the frontal thrust (Taira, Hill, Firth, et al., 1991). However, if we assume that thrusting could have induced a pressure release at the décollement, it seems possible that dissolved hydrocarbon gases were released from pore waters at the décollement, and have migrated along the frontal thrust. This assumption further implies that the gas phase must have moved faster than the liquid, and that, before the fluids 


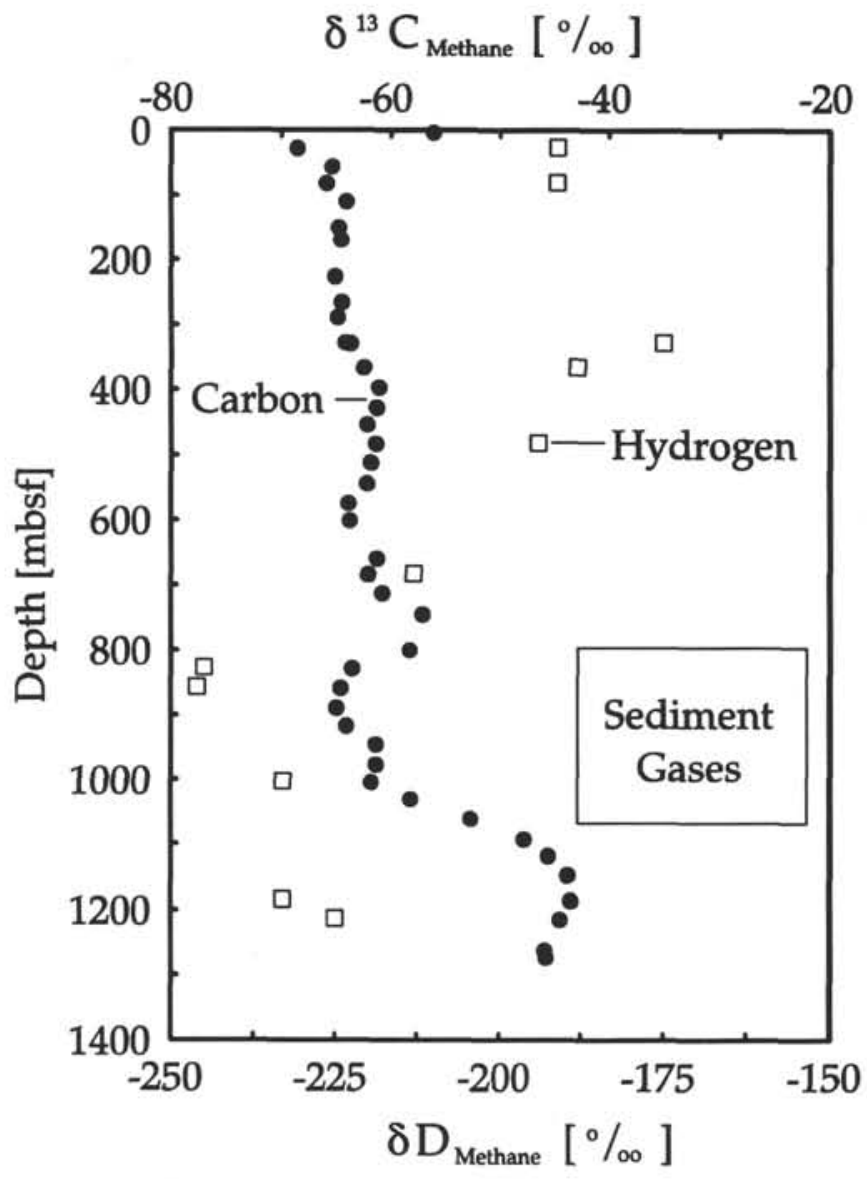

Figure 5. Carbon and hydrogen isotope ratios of methane at Site 808.

could reach the position of the thrust at Site 808 , the thrust was closed again.

Excluding migration along the frontal thrust, an alternative hypothesis would be to assume that at low temperatures in the immature sediments at $366 \mathrm{mbsf}$, propane is generated from kerogens that differ isotopically in the propane precursor functional groups from the kerogens below 600 mbsf.

\section{CONCLUSIONS}

Stable isotopes of methane and $\mathrm{CO} 2$ from gas pockets point to bacterial formation of methane by $\mathrm{CO}_{2}$-reduction, yet carbon dioxide has likely suffered isotope fractionation. Methane desorbed from sediments by a vacuum/acid treatment is of bacterial and thermal origin. Mixing between these gas types between 683 and $1061 \mathrm{mbsf}$ is obvious from molecular composition and carbon isotope ratios. The vertical concentration variations of ethane to pentane at Site 808 reflect the thermal evolution of the sedimentary organic matter. Diagenetic processes at low temperatures can explain ethane to pentane concentrations and composition from 0 and $850 \mathrm{mbsf}$. Between $850 \mathrm{mbsf}$ and the basaltic basement, hydrocarbon occurrences are related to catagenetic processes at elevated temperatures. The inversion of carbon isotope ratios of ethane and propane of samples above and below the décollement points to isotopic inhomogeneities of the precursor sites within the terrestrial derived kerogens, rather than to mixing of ethanes of different maturities. Carbon isotope values of propane of a sample from the frontal thrust indicate that gases could have migrated from sediments of a higher maturity into the immature sediments at $366 \mathrm{mbsf}$, or that propane precursor functional groups differ isotopically from those below $600 \mathrm{mbsf}$.

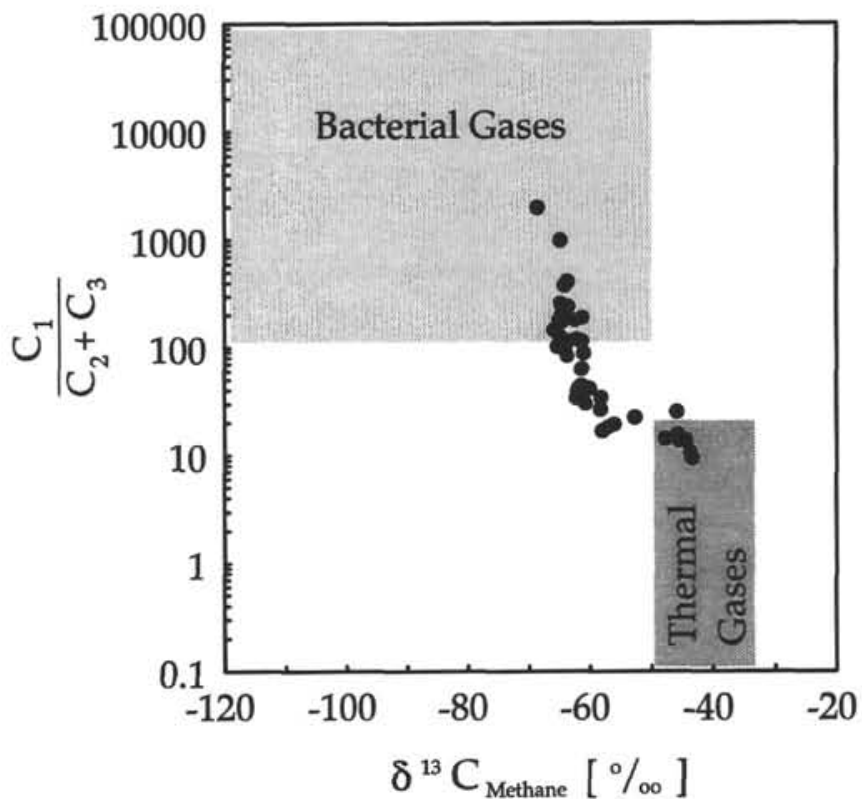

Figure 6. Carbon isotope ratios of methane and molecular ratios indicate mixing of bacterial and thermal gases at Site 808 .

\section{ACKNOWLEDGMENTS}

The authors thank Scott Chaffey of ODP for his assistance with sample collection and his patience in the freezer. Joe Peloso of ODP has done his best to provide liquid nitrogen to keep the sediments frozen. We are grateful to Michaela Frädrich, Claudia Paul, Dieter Panten, and Jürgen Poggenburg of BGR for carrying out the analytical work. The work of U. Berner was funded by the Deutsche Forschungsgemeinschaft and the German Ministry of Technology and Research. We also thank Michael Abrams, Martin Schoell, and Peter Vrolijk for their constructive comments.

\section{REFERENCES*}

Abrams, M.A., 1989. Interpretation of methane carbon isotopes extracted from surficial sediments for detection of subsurface hydrocarbons. APGE Bull., 5:139-164.

Alexander, R., Kagi, R.I., and Woodhouse, G.W., 1983. Variation in ratio of isomeric butanes with sediment temperature in Carnarvon Basin of Western Australia. In Bjoroy, M. (Ed.), Advances in Organic Geochemistry 1981: New York (Wiley), 76-79.

Bernard, B.B., 1979. Light hydrocarbons in marine sediments [Ph.D. dissert.]. Texas A\&M Univ., College Station, TX.

Berner, U., 1989. Entwicklung und Anwendung empirischer Modelle für die Isotopenvariationen in Mischungen thermogener Erdgase [Ph.D. thesis]. Technische Univ. Clausthal.

Berner, U., and Bertrand, P., 1991. Light hydrocarbons in sediments of the Sulu Sea Basin (Site 768): genetic characterization by molecular and stable isotope composition. In Silver, E.A., Rangin, C., von Breymann, M.T., et al., Proc. ODP, Sci. Results, 124: College Station, TX (Ocean Drilling Program), 227-232.

Berner, U., Dumke, I., Faber, E., and Poggenburg, J., 1990. Organic geochemistry of surface sediments of the Sulu Trench/Philippines. In Rangin, C., Silver, E.A., von Breymann, M.T., et al., Proc. ODP, Init. Repts., 124: College Station, TX (Ocean Drilling Program), 113-118.

Berner, U., and Faber, E., 1988. Maturity related mixing model for methane, ethane and propane, based on carbon isotopes. In Advances in Organic Geochemistry 1987, 67-72.

* Abbreviations for names of organizations and publications in ODP reference lists follow the style given in Chemical Abstracts Service Source Index (published by American Chemical Society). 
Berner, U., Faber, E., and Stahl, J.W., 1992. Mathematical simulation of carbon isotope fractionation between huminitic coals and methane. Isotope Geol., 94:315-319.

Berner, U., von Breymann, M.T., Faber, E., and Bertrand, P., 1992. Gas geochemistry of ODP Sites 767 and 768, Celebes and Sulu Seas. In Vially, R. (Ed.), Bacterial Gases: Paris (Edition Technip.).

Chung, H.M., Gromly, J.R., and Squires, R.M., 1988. Origin of gaseous hydrocarbons in subsurface environments: theoretical considerations of carbon isotope distribution. Chem. Geol., 71:97-103.

Coleman, D.D., Risatti, J.B., and Schoell, M., 1981. Fractionation of carbon and hydrogen isotopes by methane-oxidising bacteria. Geochim. Cosmochim. Acta, 45:1033-1037.

Coleman, M.L., Shepherd, T.J., Durham, J.J., Rouse, J.E., and Moore, G.R., 1982. Reduction of water with zinc for hydrogen isotope analysis. Anal. Chem., 54:993-995.

Dumke, I., Faber, E., and Poggenburg, J., 1989. Determination of stable carbon and hydrogen isotopes of light hydrocarbons. Anal. Chem., 61:2149-2154.

Durand, B., and Espitalié, J., 1972. Formation et evolution des hydrocarbures $\mathrm{C}_{1}$ a $\mathrm{C}_{15}$ et des gaz permanents dans les argiles du toarcian du bassin de Paris. In Gaertner, H.R., and Wehner, H. (Eds.), Advances in Organic Geochemistry 1971: Braunschweig (Pergamon), 455-468.

Evans, C.R., and Staplin, F.L., 1971. Regional facies of organic metamorphism in geochemical exploration. 3rd Int. Geochem. Expl. Symp. Proc., Can. Inst. Min. Metal., 11:517-520.

Faber, E., 1987. Zur Isotopengeochemie gasförmiger Kohlenwasserstoffe. Erdoel, Erdgas, Kohle, 103:210-218.

Faber, E., and Stahl, J.W., 1983. Analytical procedure and results of an isotope geochemical surface survey in an area of the British North Sea. In Brooks, J. (Ed.), Petroleum Geochemistry and Exploration of Europe. Geol. Soc. Spec. Publ. London, 11:51-63.

Fuex, A.N., 1977. The use of stable carbon isotopes in hydrocarbon exploration. J. Geochem. Explor., 7:155-188.

Games, L.M., and Hayes, J.M., 1976. On the mechanisms of $\mathrm{CO}_{2}$ and $\mathrm{CH}_{4}$ production in natural anaerobic environments. Proc. Environ. Biogeochem., 51-73.

Horvitz, L., 1972. Vegetation and geochemical prospecting for petroleum. AAPG Bull., 546:925-940.

Hunt, J.M., 1979. Petroleum Geochemistry and Geology: San Francisco (W.H. Freeman).

James, A.T., 1983. Correlation of natural gas by use of carbon isotopic distribution between hydrocarbon components. AAPG Bull., 67:1176-1191.
1990. Correlation of reservoired gases using the carbon isotopic compositions of wet gas components. AAPG Bull., 74:1441-1458.

Jenden, P.D., Newell, K.D., Kaplan, I.R., and Watney, W.L., 1988. Composition and stable isotope geochemistry of natural gases from Kansas, midcontinent, USA. Chem. Geol., 71:117-147.

Leythaeuser, D., Altebaeumer, F.J., and Weiner, B., 1979. Generation of low molecular weight hydrocarbons from organic matter in source beds as a function of temperature and facies. Chem. Geol., 25:95-108.

McCarty, H.B., and Felbeck, G.T., 1986. High temperature simulation of petroleum formation-IV. Stable carbon isotope studies of gaseous hydrocarbons. Org. Geochem., 9:183-192.

Rashid, M.A.(Ed.), 1985. Geochemistry of Marine Humic Compounds: Berlin (Springer-Verlag).

Richet, P., Bottinga, Y., and Javoy, M., 1977. A review of hydrogen, carbon, nitrogen, oxygen, sulphur and chlorine stable isotope fractionation among gaseous molecules. Annu. Rev. Earth Planet. Sci., 5:65-110.

Schaefer, R.G., and Leythaeuser, D., 1983. Generation and migration of low-molecular weight hydrocarbons in sediments from Site 511 of DSDP/IPOD Leg 71. Falkland Plateau, South Atlantic. In Bjoroy, M. (Ed.), Advances in Organic Geochemistry 1981: New York (Wiley), 164-174.

Schoell, M., 1984. Wasserstoff- und Kohlenstoffisotope in organischen Substanzen, Erdölen und Erdgasen. Geol. Jahrb., Reihe D D67.

Stahl, J.W., 1977. Carbon and nitrogen isotopes in hydrocarbon research and exploration. Chem. Geol., 20:121-149.

Stahl, J.W., and Carey, B.D., 1975. Source-rock identification by isotope analyses of natural gases from fields in the Val Verde and the Delaware Basins, West Texas. Chem. Geol., 16:257-267.

Taira, A., Hill, I., Firth, J.V., et al., in press. Proc. ODP, Init. Repts., 131: College Station, TX (Ocean Drilling Program).

Tissot, B.P., and Welte, D.H., 1984. Petroleum Formation and Occurrence (2nd ed.): Heidelberg (Springer-Verlag)

Whiticar, M.J., and Faber, E., 1986. Methane oxidation in sediment and water column environments-isotope evidence. Org. Geochem., 10:759-768.

Whiticar, M.J., Faber, E., and Schoell, M., 1986. Biogenic methane formation in marine and freshwater environments: $\mathrm{CO}_{2}$ reduction vs. acetate fermentation-isotope evidence. Geochim. Cosmochim. Acta, 50:693-709.

Date of initial receipt: 9 October 1991

Date of acceptance: 7 October 1992

Ms 131SR-120 


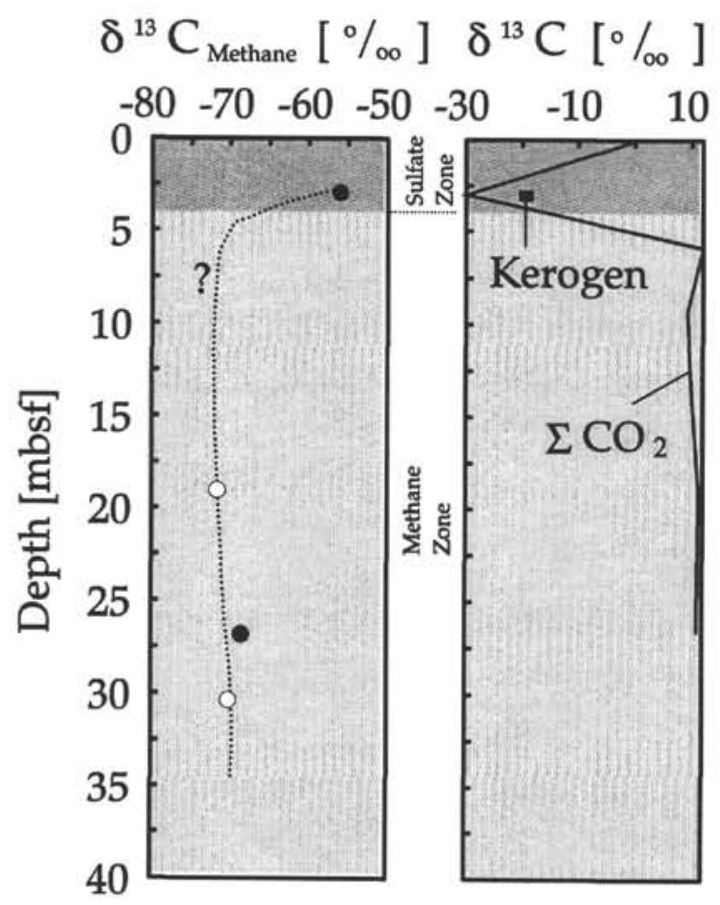

Figure 7. Changes of carbon isotope ratios of methane and $\Sigma \mathrm{CO}_{2}$ indicate oxidation of diffused methane in the sulfate reduction zone of Site $808\left(\mathrm{\Sigma CO}_{2}\right.$ data from Gamo et al., this volume; kerogen isotope data from Berner and Koch, this volume).

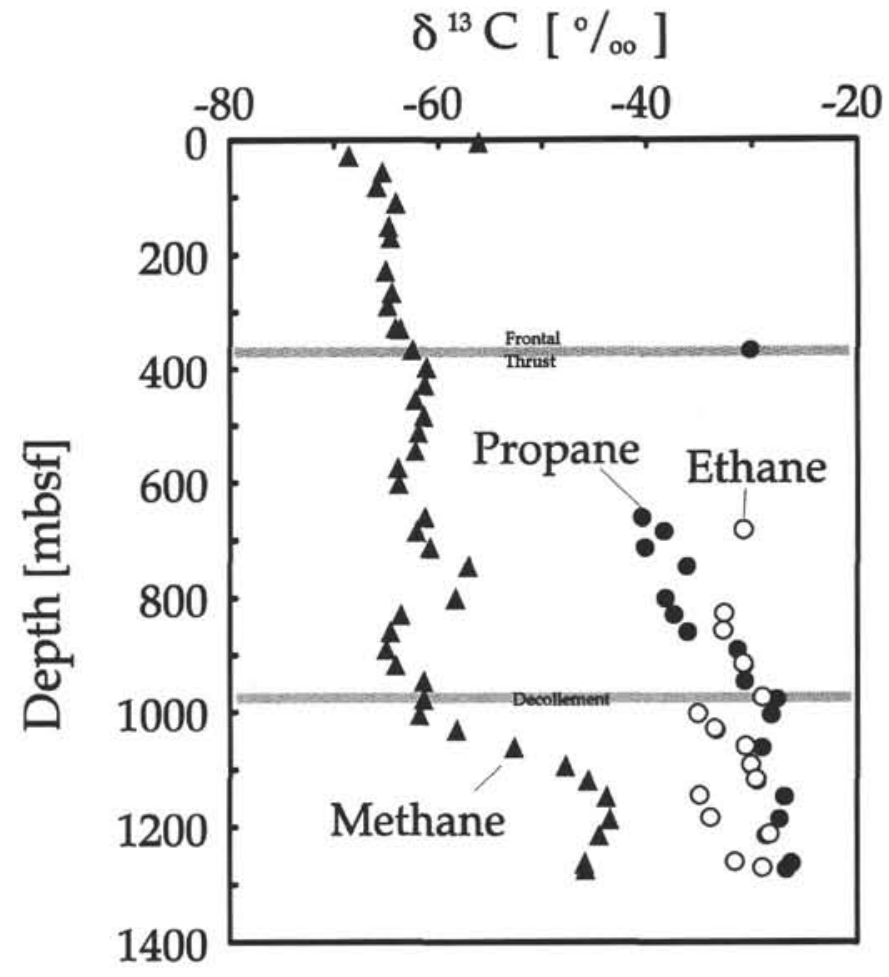

Figure 8. Carbon isotope ratios of methane, ethane, and propane at Site 808.

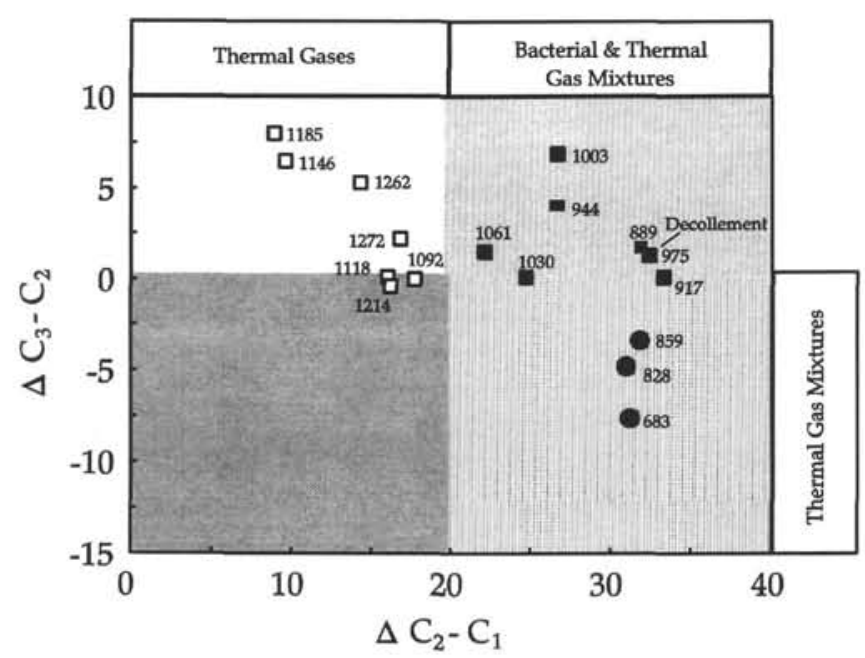

Figure 9. Classification of gas mixtures using carbon isotopic differences of methane, ethane, and propane. 
Table 3. Gas ratios and stable isotopic composition of gases from Site 808.

\begin{tabular}{|c|c|c|c|c|c|c|c|c|}
\hline $\begin{array}{l}\text { Core, section, } \\
\text { interval }(\mathrm{cm})\end{array}$ & $\begin{array}{l}\text { Depth } \\
\text { (mbsf) }\end{array}$ & $\mathrm{i} / \mathrm{nC}_{4}$ & $\mathrm{i} / \mathrm{nC}_{5}$ & $\frac{C_{1}}{C_{2}+C_{3}}$ & $\begin{array}{l}\delta^{13} \mathrm{C}_{1} \\
(\% 0)\end{array}$ & $\begin{array}{l}\delta^{13} \mathrm{C}_{2} \\
(\%))^{2}\end{array}$ & $\begin{array}{l}\delta^{13} \mathrm{C}_{3} \\
(\%))^{2}\end{array}$ & $\begin{array}{l}\delta D_{1} \\
(\%)\end{array}$ \\
\hline $\mathrm{A}-1 \mathrm{H}-2,145-150$ & 2.95 & 0.87 & 1.88 & 19.5 & -56.1 & - & - & - \\
\hline A- $4 \mathrm{H}-2,0-5$ & 26.80 & - & - & 1999.0 & -68.6 & - & - & -191 \\
\hline A-7H-1, 145-150 & 55.25 & 0.92 & 1.00 & 102.5 & -65.4 & - & - & - \\
\hline A- $10 \mathrm{H}-3,15-20$ & 80.95 & 1.38 & 2.60 & 145.5 & -65.9 & - & - & -191 \\
\hline A-13H-2, 145-150 & 108.69 & 1.00 & 0.67 & 383.3 & -64.1 & - & - & - \\
\hline B-5X-1 & 149.50 & 1.80 & 2.50 & 261.6 & -64.8 & 一 & - & - \\
\hline B-7X-1 & 168.80 & 1.60 & 3.00 & 174.0 & -64.6 & - & - & - \\
\hline B-13X-1 & 225.80 & 1.00 & 2.50 & 180.5 & -65.1 & -29.9 & - & - \\
\hline B-17X-2 & 264.90 & 1.00 & 2.00 & 242.4 & -64.5 & - & - & - \\
\hline B-20X-1 & 287.90 & 1.00 & 1.00 & 998.7 & -64.9 & - & - & - \\
\hline C-4R-1 & 327.20 & 1.67 & 3.00 & 225.1 & -64.2 & - & - & - \\
\hline B- $24 X-2$ & 327.90 & 1.50 & 3.00 & 415.3 & -63.7 & - & - & -175 \\
\hline C-8R-1 & 365.90 & 2.33 & 2.00 & 180.5 & -62.5 & - & -30.2 & -188 \\
\hline C-11R-2 & 396.30 & 1.80 & 4.67 & 88.6 & -61.1 & - & - & - \\
\hline C-14R-3 & 427.00 & 2.00 & 1.40 & 190.8 & -61.3 & - & - & - \\
\hline C-17R-1 & 452.70 & 6.00 & - & 119.0 & -62.2 & - & - & - \\
\hline C-20R-1 & 481.70 & 6.00 & 5.00 & 114.9 & -61.4 & - & - & -194 \\
\hline C-23R-1 & 510.70 & 4.20 & - & 41.8 & -61.9 & - & - & - \\
\hline$C-26 R-3$ & 542.70 & 5.55 & 5.50 & 33.8 & -62.2 & - & - & - \\
\hline C- $29 \mathrm{R}-4$ & 573.10 & 3.00 & - & 116.3 & -6.9 & - & - & - \\
\hline C- $32 R-3$ & 600.30 & 5.67 & 5.00 & 84.2 & -63.8 & - & - & - \\
\hline C- $35 R-4$ & 630.70 & 7.25 & 3.10 & 41.6 & - & - & - & - \\
\hline C-38R-4 & 659.40 & 10.25 & 8.50 & 33.1 & -61.3 & - & -40.5 & - \\
\hline C-4IR-1 & 683.80 & 4.50 & 16.00 & 39.1 & -62.1 & -30.8 & -38.4 & -213 \\
\hline C-44R-1 & 712.40 & 7.00 & 9.00 & 30.4 & -60.8 & - & -40.2 & - \\
\hline$C-47 R-3$ & 744.40 & 4.87 & 22.00 & 18.3 & -57.1 & - & -36.2 & - \\
\hline C-50R-5 & 776.40 & 7.33 & 15.75 & 17.0 & - & - & - & - \\
\hline C-53R-1 & 799.40 & 6.40 & 8.50 & 26.9 & -58.3 & - & -38.2 & - \\
\hline C-56R-1 & 828.40 & 5.00 & - & 242.7 & -63.6 & -32.6 & -37.4 & -245 \\
\hline C- 59 R-2 & 858.60 & 2.00 & 1.00 & 202.9 & -64.6 & -32.7 & -36.1 & -246 \\
\hline C- $62 R-3,0-5$ & 889.10 & 1.33 & 1.00 & 128.7 & -65.0 & - & -31.4 & - \\
\hline C-65R-1, 145-150 & 916.55 & 1.75 & 3.00 & 95.0 & -64.1 & -30.8 & -30.7 & - \\
\hline C-68R-1, 15-20 & 944.35 & 1.00 & 1.00 & 63.4 & -61.4 & - & -30.7 & - \\
\hline C-71R-2, 115-120 & 975.75 & 0.92 & 1.40 & 44.5 & -61.4 & -29.0 & -27.7 & - \\
\hline C-74R-2, 0-5 & 1003.30 & 0.75 & 0.80 & 35.8 & -61.8 & -35.1 & -28.2 & -233 \\
\hline C-77R-1, 0-5 & 1029.90 & 0.73 & 1.00 & 34.6 & -58.2 & -33.5 & -33.4 & - \\
\hline C- $80 R-2,120-125$ & 1060.50 & 0.93 & 0.57 & 22.5 & -52.7 & -30.6 & -29.1 & - \\
\hline C-84R-1 & 1092.00 & 0.97 & 0.65 & 14.3 & -47.8 & -30.1 & -30.1 & - \\
\hline C-87R-1 & 1117.60 & 0.97 & 0.64 & 13.7 & -45.6 & -29.6 & -29.5 & - \\
\hline C-90R-1 & 1146.30 & 1.42 & 0.74 & 10.6 & -43.8 & -34.9 & -26.9 & - \\
\hline C-94R-1 & 1184.90 & 1.83 & 0.59 & 9.5 & -43.5 & -33.9 & -27.4 & -233 \\
\hline C-97R-1 & 1214.00 & 0.63 & 0.46 & 13.7 & -44.5 & -28.3 & -28.7 & -225 \\
\hline C-102R-1 & 1261.50 & 0.40 & 0.00 & 25.4 & -45.9 & -31.6 & -26.3 & - \\
\hline C-103R-2 & 1272.40 & 0.69 & 1.92 & 15.5 & -45.8 & -29.0 & -26.8 & - \\
\hline
\end{tabular}




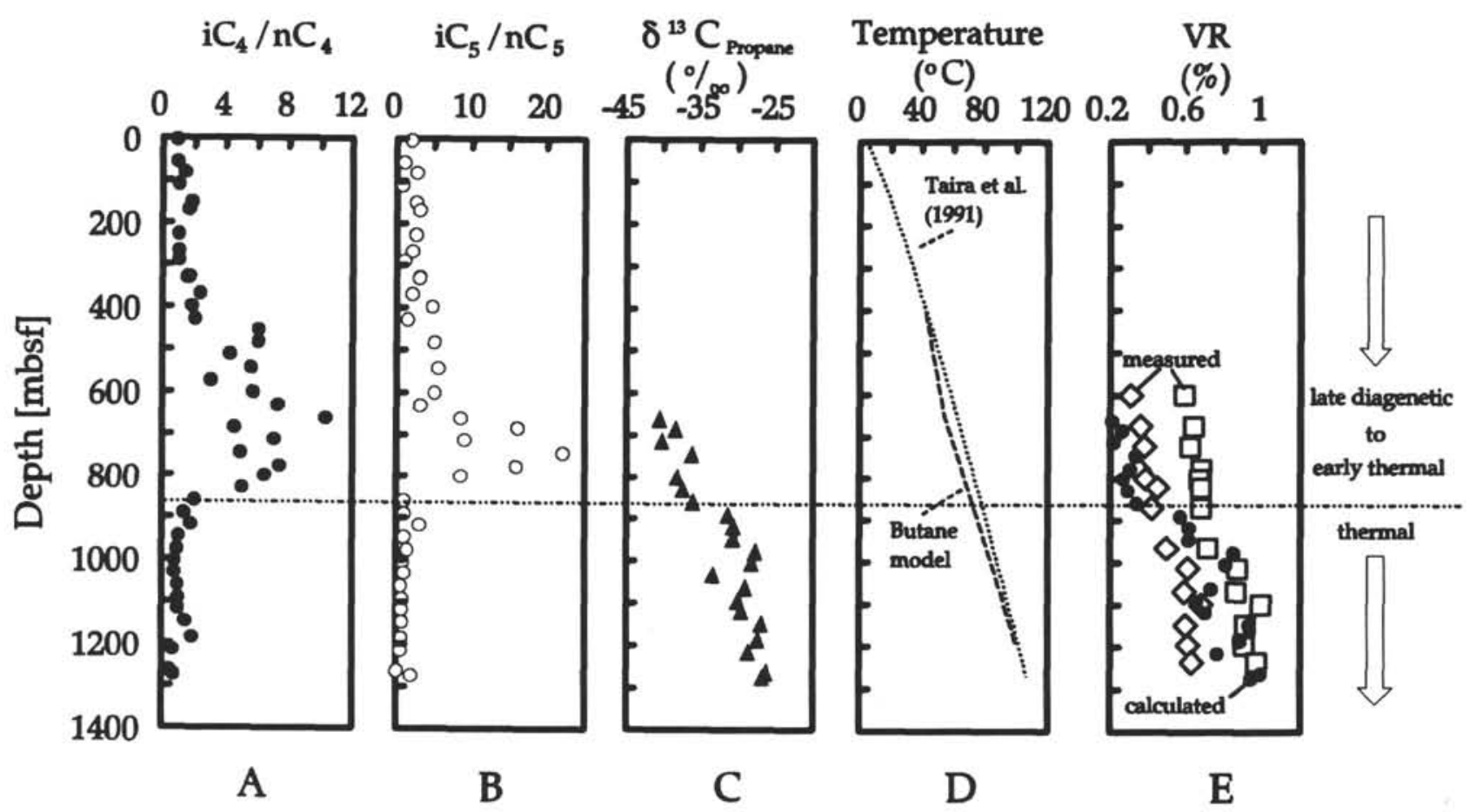

Figure 10. Vertical changes of butane ratios at Site 808 (A). The related temperature model (D) is similar to the temperature measurements and prediction of Taira, Hill, Firth, et al. (1991). Pentane ratios (B) show a similarity to the vertical distribution of butane ratios. Carbon isotope ratios of propane increase with increasing depth at Site 808 (C). The calculated vitrinite reflectance equivalents suggest immature sediments down to 850 mbsf and mature organic matter between 850 and the basement (E).

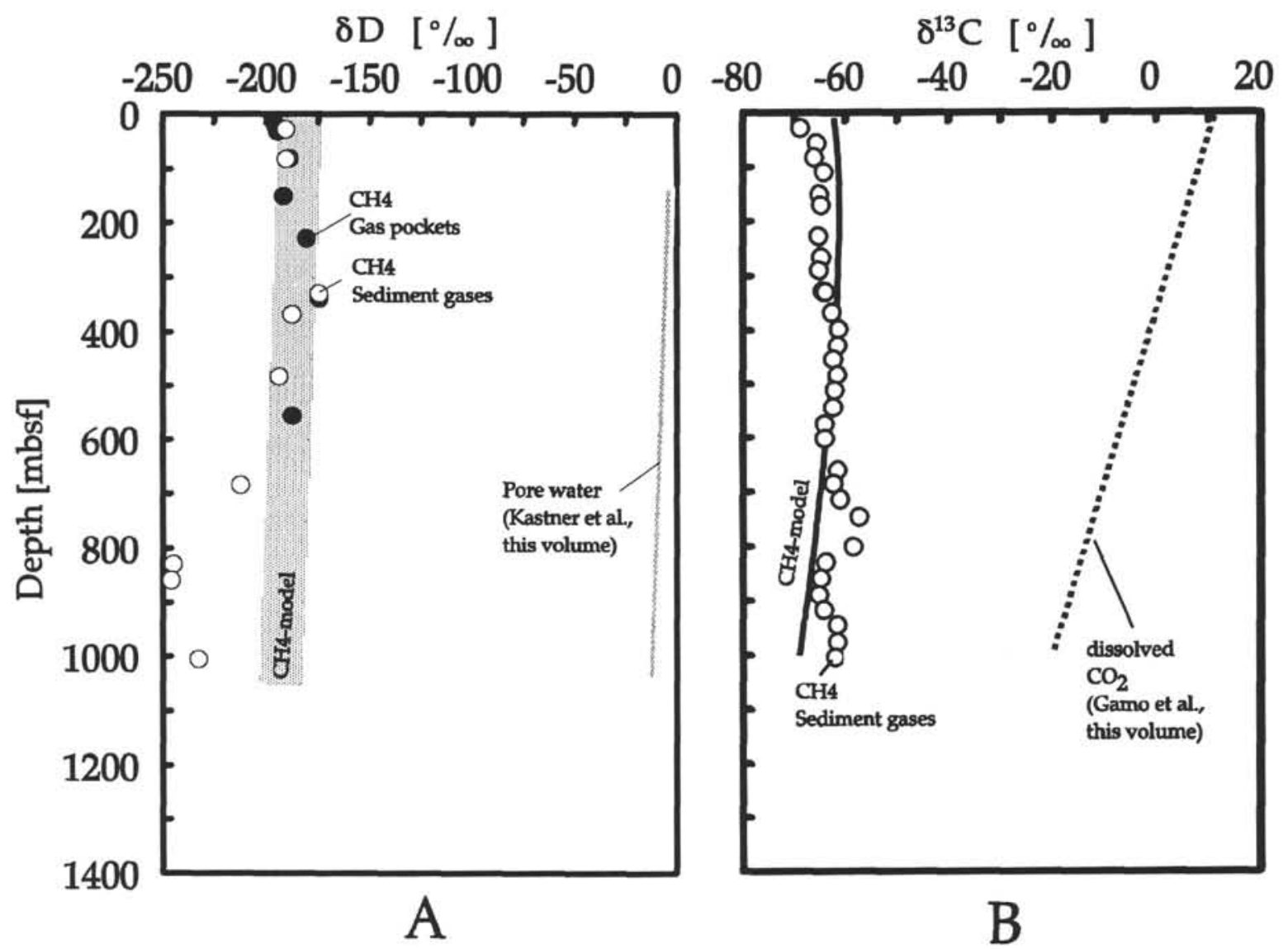

Figure 11. Hydrogen (A) and carbon (B) isotope ratios of bacterial methanes of Site 808 in comparison with geochemical models. Trends of hydrogen isotope ratios of pore waters and carbon isotope ratios of total dissolved carbon dioxide have been taken from Kastner et al. (this volume) and Gamo et al. (this volume), respectively. 